EASTERN MEDITERRANEAN

'Under the Mediterranean' The Honor Frost Foundation Conference on Mediterranean Maritime Archaeology 20th -23 rd October 2017 Short Report Series.

doi: https://doi.org/10.33583/utm2020.07

(C) 2020 The Author

\title{
The Tonnage of the Syracusia: a metrological reconsideration
}

\section{Dr Emmanuel Nantet}

Leon Recanati Institute for Maritime Studies, University of Haifa, Israel

The tonnage of the Syracusia, the biggest ship built in the ancient Mediterranean, has been much discussed by scholars. Indeed, the various merchandise the ship carried are detailed by Athenaeus, who relies on a text previously written by Moschion. However, the value of the units of measurements used in Athenaeus' account are not well known. So far, scholars have suggested only either Athenian or Roman units of measurement. The present report aims at exploring the possibility of local metrological systems, such as Ptolemaic or Sicilian ones, as Moschion and Athenaeus respectively lived in Sicily and in Alexandria.

\section{Key words}

Metrology, tonnage, cargo, wheat, giant ship, Sicily

The Syracusia is known as the biggest ship built in ancient times (5, 206d-209e). The ship was built by Archias of Corinth, to fulfill an order from king Hiero II (269-215 BCE). The construction was supervised by Archimedes (Salviat, 1987; Zevi, 2001; Pomey \& Tchernia, 2006; Castagnino Berlinghieri, 2010; Nantet, 2016:12-131). Big the ship certainly was, but how big exactly? Many scholars have focused on that giant ship in order to assess the maximum tonnage allowed by the construction techniques in Hellenistic times (Rougé, 1984; Casson, 1971; Pomey \& Tchernia, 1978). Of course, the contents of the cargo are precisely described (Athenaeus, Deipnosophistae, 209a): 
The vessel was loaded with 60,000 measures of grain, 10,000 jars of pickled

Sicilian fish, 20,000 talents of wool, and 20,000 talents of miscellaneous cargo.

(Trans. Lionel Casson, Princeton, University Press, 1995 [1 st ed. 1971]).

Tzetzes, a poet of the 12th century CE, tells that the cargo included 50,000 medimni of corn (Tzetzes, Chiliades, 2, 35, 106-111):

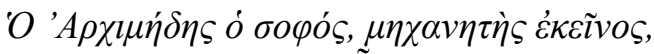

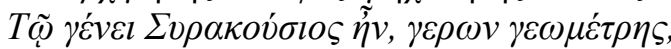

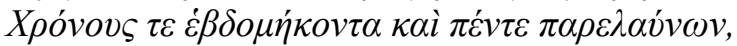

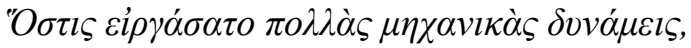

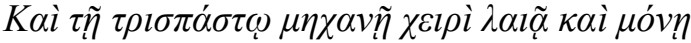

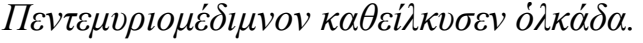

Wise Archimedes, that machinist,

Was a Syracusan by race, an old geometrician

And driving past seventy-five seasons,

A man who built many mechanical capacities,

Even with the three-pulley machine, with the left and only hand

He drew to the sea a trading vessel burdened with fifty thousand medimni.

Trans. Gary Berkowitz (modified)

According to Elena Flavia Castagnino Berlinghieri, this ship was constructed in the Syracusan shipyard as both a floating palace and a warship (Castagnino Berlinghieri, 2010:185-186). The vessel may then have been layed up and converted to a commercial ship just before being given to the Ptolemies. Indeed, the contents of the cargo is detailed just a few lines before the description of the vessel being given to Ptolemy (Athenaeus, Deipnosophistae, 209b), maybe Ptolemy II (Castagnino Berlinghieri, 2010:note 14). However, as Fausto Zevi emphasizes (Zevi, 2001), the Syracusia was designed first as a grain carrier (Atheaneus, Deipnosophistae, 206e). It should also be underlined that the numerous estimations conducted so far by most of the scholars rely on the contents of the cargo. Therefore, the aim is to provide the weight of the cargo carried by Syracusia for the journey related in Athenaeus' account. The latter has to be considered as the deadweight tonnage, i.e. the load capacity of the ship that is dedicated to the cargo, notwithstanding that the ship could be intentionally under- or overloaded. This approach should not be mistaken with the calculations intended to estimate displacement, which relies not only on the weight of the cargo, but also the weight of the ship itself, including the hull, the rigging, the crew, etc (Turfa-Steinmayer, 1999). Of course, these kinds of calculations rely on many unknown parameters and should be considered with caution. Thus, the only reliable approach consists in estimating the weight of the cargo, whose contents are detailed by Athenaeus.

\section{The estimation of the cargo with medimni}

The estimation of the weight of the cargo is rendered unmeasurable by metrological factors. Indeed, what metrological system was used in the account given by Athenaeus? He does not point out any specific unit of measurement for the cargo of grain. At first, many scholars (Torr, 1894: 27; Graser, 1864: 48; Frank, 1933: 105; Duncan-Jones, 1977: 332; Rougé 1984: 226-230) considered it should be the Attic medimnos (52 1). Indeed, Tzetzes, a Byzantine poet, mentions the medimnos, which could support this idea. However, this evidence is very late. The use of the medimnos looks even stranger since this unit of measurement has not 
been used for more than a millennium. Therefore, the choice of the medimnos allows a huge tonnage (4000 tonnes approx.), far beyond the several hundred tonnes carried by the myriophoroi - the biggest ships mentioned in the written evidence (Nantet, 2012, 2016: 115-116). Jean Rougé, who doubted such a gigantic ship could have existed, considers that the Syracusia was nothing but a 'sea monster', surely more a legend than a historical fact.

\begin{tabular}{|l|c|c|}
\hline $\begin{array}{l}\text { Merchandise (in ancient } \\
\text { units of measurement) }\end{array}$ & $\begin{array}{c}\text { Unit weight of the } \\
\text { merchandise (in kg) }\end{array}$ & $\begin{array}{c}\text { Weight of each cargo } \\
\text { (in tonnes) }\end{array}$ \\
\hline $\begin{array}{l}60,000 \text { 'measures' of } \\
\text { wheat }\end{array}$ & 40 (medimnos of 52 1)? & 2400 \\
\hline $\begin{array}{l}10,000 \text { keramia Sicilian } \\
\text { salt-fish }\end{array}$ & 50 (amphora) & 500 \\
\hline $\begin{array}{l}20,000 \text { talents of wool } \\
20,000 \text { talents of other } \\
\text { merchandise }\end{array}$ & 26 (talent) & 520 \\
\hline
\end{tabular}

Table 1: Estimation of the cargo with medimni

\section{The estimation of the cargo with modii}

However, Lionel Casson emphasizes that Athenaeus lived in the Roman period, i.e. five centuries after the event he relates (Casson, 1956-1957, 1995: 184-186). He notes that the medimnos is no longer in use in the Roman period, which is accurate. He suggests that Athenaeus may have decided to adapt his text to his audience. Therefore, the Roman writer would have substituted the modius $(8.733 \mathrm{l})$ for the medimnos and therefore converted the amount of corn.

Thus, the choice of the modius led to an enormous decrease of the grain cargo — and of the tonnage, reducing them respectively to a mere 400 and 1940 tonnes. At first, Lionel Casson even chose a weight of $25 \mathrm{~kg}$ for the keramion (Casson, 1956-1957 :232-233), which provided a weight of 1650 tonnes only for the whole cargo. Fifteen years later, he changed for a more relevant weight of 50kg, which produced a higher weight of 1940 tonnes for the cargo. 


\begin{tabular}{|l|c|c|}
\hline $\begin{array}{l}\text { Merchandise (in ancient } \\
\text { units of measurement) }\end{array}$ & $\begin{array}{c}\text { Unit weight of the } \\
\text { merchandise (in kg) }\end{array}$ & $\begin{array}{c}\text { Overall weight of the } \\
\text { cargo (in tonnes) }\end{array}$ \\
\hline $\begin{array}{l}60,000 \text { 'measures' of } \\
\text { wheat }\end{array}$ & $\begin{array}{c}66 \text { (Roman modius of } \\
8733 \text { 1)? }\end{array}$ & 400 \\
\hline $\begin{array}{l}10,000 \text { keramia Sicilian } \\
\text { salt-fish }\end{array}$ & 50 (amphora) & 500 \\
\hline $\begin{array}{l}20,000 \text { talents of wool } \\
20,000 \text { talents of other } \\
\text { merchandise }\end{array}$ & 26 (talent) & 520 \\
\hline
\end{tabular}

Table 2: Estimation of the cargo with modii

Nevertheless, he was not followed by R.P. Duncan-Jones (Duncan-Jones, 1977), nor Jean Rougé (Rougé, 1984), who both objected that this choice would not be in accordance with the fame of the ship, renowned as a huge grain carrier. Moreover, it should be noted that the modius was not used in Egypt, when Athenaeus was alive (Mayerson, 2006).

It should be also noted that the talent of $26 \mathrm{~kg}$ used by all these scholars, including Rougé and Casson, is surely not relevant. Indeed, this talent was used in the Attic metrological system during the Classical period. It was no longer used in the Hellenistic and Roman periods, and therefore should be rejected in the estimation of Syracusia's tonnage.

In spite of these reservations, Casson was followed by Jean MacIntosh Turfa and Alwin G. Niemeyer, who based their numerous calculations on his estimation (Turfa-Steinmayer, 1999: note 9).

\section{The estimation of the cargo with Ptolemaic units of measurement (artabae).}

It has not previously been considered that the unit of measurement mentioned by Athenaeus, who lived in Naucratis, may have been the artaba, which was the usual unit of measurement of tonnage used in Egypt between the Persian and the Byzantine periods. Could it be that Athenaeus did not mention a specific unit of measurement because it was obvious to his readers? Whoever read his account would not be mistaken; this unit was clearly the artaba.

The reconsideration of the units of measurement mentioned by Athenaeus allows us to estimate a tonnage of 2580 tonnes (with an artaba of 29.107 1, see Mayerson, 2006). It provides a weight of 1362 tonnes for the cargo of corn, which is more or less the same as the capacity of the Isis, another huge and famous grain-carrier (Lucian, Navigium, 5; see Pomey and Tchernia, 1978). As the value of the artaba is still discussed, it should not be excluded that the weight of the cargo could have been 2904 tonnes, including 1686 tonnes of corn (with an artaba of 38 1, i.e. $28.1 \mathrm{~kg}$, see Duncan-Jones, 1976). 


\begin{tabular}{|l|c|c|}
\hline $\begin{array}{l}\text { Merchandise (in ancient } \\
\text { units of measurement) }\end{array}$ & $\begin{array}{c}\text { Unit weight of the } \\
\text { merchandise (in kg) }\end{array}$ & $\begin{array}{c}\text { Overall weight of the } \\
\text { cargo (in tonnes) }\end{array}$ \\
\hline $\begin{array}{l}60,000 \text { 'measures' of } \\
\text { wheat }\end{array}$ & 22.7 (artaba of 29.107 1)? & 1362 \\
\hline $\begin{array}{l}10,000 \text { keramia Sicilian } \\
\text { salt-fish }\end{array}$ & 40 (amphora) & 400 \\
\hline $\begin{array}{l}20,000 \text { talents of wool } \\
\text { merchandise talents of other }\end{array}$ & 20.46 (Ptolemaic talent) & 409 \\
\hline & \multicolumn{2}{|c|}{} \\
\hline
\end{tabular}

Table 3: Estimation of the cargo with artabae

As for the talent used for the wool and other merchandise, its value in the Ptolemaic metrological system was $20.46 \mathrm{~kg}$. And then what about the Sicilian keramia mentioned by Athenaeus? The inquiry conducted by Emmanuel Botte in Sicily led to the identification of a "tubular amphora" (Botte, 2009, 2012). It is called Type T-7.6.3.1, and is related to a Punic tradition. It was surely made for tuna. That specific type of amphora was produced in Sicily, and has been found all over the Mediterranean, especially in the Eastern part. Its height ranges $100-108 \mathrm{~cm}$ and its maximum width from $16-20 \mathrm{~cm}$. Although its capacity is not known, its dimensions are close to Dressel 21-22 amphoras. Thus, its capacity may have been approximately 201 that is a weight of $40 \mathrm{~kg}$ when full. Certainly, this amphora is well known all through the 2 nd and 1 st centuries BCE. Therefore, it is slightly earlier than Syracusia. This is the closest parallel that can be found. The salt-fish keramia mentioned by Athenaeus was surely not very different from that amphora.

\section{The estimation of the cargo with Sicilian units of measurement}

As the Syracusia was built in Sicily, the use of a Sicilian unit of measurement should be considered, too. Indeed, the account given by Athenaeus was written first by Moschion, a poet of the 3 rd century BCE, maybe from Syracuse (Cambiano, 1996). Fortunately, the Sicilian metrological system is now better known. Indeed, several cylindric vessels with grooves around the body were found in Morgantina and other south-eastern Sicilian cities. They have been interpreted by Walthall as grain measures. Their capacity was 32 1, i.e. a weight of $25 \mathrm{~kg}$. They were surely used whilst Hiero II reigned over the island (Walthall, 2011: figs 3 \& 4).

And what was the weight of the talent in his kingdom? The weight of the drachma was $3.36 \mathrm{~g}$, which gives a talent of $20.16 \mathrm{~kg}$ (Caccamo Caltabiano, 1995; Cattamo Caltabiano et al., 1997).

It is worth noting that many Sicilian units of measurement are close to Ptolemaic ones. In fact, this is not surprising, as Sicilian and Ptolemaic kings had close relationships (Manganaro, 1989; Santagati Ruggeri, 
1996; Caccamo Caltabiano et al., 2004). When Hiero offered the Syracusia to Ptolemy II, the gift showed how deeply this alliance was rooted between the two Hellenistic kingdoms.

\begin{tabular}{|l|c|c|}
\hline $\begin{array}{l}\text { Merchandise (in ancient } \\
\text { units of measurement) }\end{array}$ & $\begin{array}{c}\text { Unit weight of the } \\
\text { merchandise (in kg) }\end{array}$ & $\begin{array}{c}\text { Overall weight of } \\
\text { the cargo (in } \\
\text { tonnes) }\end{array}$ \\
\hline $\begin{array}{l}60,000 \text { 'measures' of wheat } \\
\text { fish }\end{array}$ & 25 (Sicilian unit of 32 1) & 1500 \\
\hline 20,000 talents of wool 40 (amphora) & 400 \\
\hline $\begin{array}{l}20,000 \text { talents of other } \\
\text { merchandise }\end{array}$ & 20.16 (Syracusan talent) & 403 \\
\hline \multicolumn{2}{|l}{} & 403 \\
\hline
\end{tabular}

Table 4: Estimation of the cargo with Sicilian units of measurement

\section{Conclusion}

It is not easy to determine with absolute certainty the units of measurement used by Athenaeus, but it seems that a more accurate analysis shows that the author surely relied on another metrological system than the Athenian or Roman ones. More probably, he used the Ptolemaic or Sicilian units of measurement. Egyptian or Sicilian? This metrological issue makes the link with two locations, Sicily and Alexandria, which played a significant role in Honor Frost's research. However, the difference is not significant (2 580 and 2706 tonnes).

\section{Acknowledgments}

I am thankful to Patrice Pomey for his numerous indications about this research, as well as Edith Ochs and Alon Pinkas, for their proofreading.

\section{Reference List}

Botte, E., 2009. L'exportation du thon sicilien à l'époque tardo-républicaine. MEFRA 124-2 (http://journals.openedition.org/mefra/887).

Botte, E., 2012. Salaisons et sauces de poissons en Italie du sud et en Sicile durant l'Antiquité. Naples, Centre Jean Bérard. 
Caccamo Caltabiano, M., ed., 1995, La Sicilia tra l'Egitta e Roma : la monetazione siracusana dell'eta di Ierone II : atti del Seminario di studi (Messina, 2-4 Dicembre 1993, Universita degli studi di Messina). Messina, Accademia peloritana.

Caccamo Caltabiano, M., Campagna, L., Pinzone, A., eds., 2004. Nuove prospettive della ricerca sulla Sicilia del III sec. a.C. Archeologia, Numismatica, Storia. Messina, Dipartimento di Scienze dell'Antichità dell'Università degli Studi di Messina.

Caccamo Caltabiano, M., Carrocio, B., Oteri, E., eds., 1997. Siracusa ellenistica. Le monete "regali" di Ierone II, della sua famiglia e dei Siracusani. Messina, Dipartimento di Scienze dell'Antichità dell'Università degli Studi di Messina.

Cambiano, G., 1996. Alle origini della meccanica: Archimede e Archia. Arachnion 2/1: 1-18.

Casson, L., 1956-1957. The size of ancient merchant ships. In: Studi in onore di Aristide Calderini e di Roberto Paribeni. Milan, Ceschina, vol. 1: 231-238.

Casson, L., 1995. Ships and Seamanship in the Ancient World. London, Johns Hopkins University Press (1st ed. 1971).

Castagnino Berlinghieri, E.F., 2010. Archimede alla corte di Hierone II: dall'idea al progetto della della più grande nave del mondo antico, la Syrakosia. In: Braccesi, L., F. Raviolo. G. Sassatelli, eds., Hesperia, 26, Studi sulla grecità di Occidente, L’Erma di Bretschneider: 169-188.

Duncan-Jones, R.P., 1976. The choenix, the artaba and the modius. ZPE 21: 43-52.

Duncan-Jones, R.P., 1977. Giant cargo-ships in antiquity. CQ 27: 331-332.

Frank, T., 1933. An Economic Survey of Ancient Rome I. Rome and Italy of the Republic. Baltimore, The Johns Hopkins Press.

Graser, B., 1864. De veterum re navali. Berlin, Berolini.

Manganaro, G., 1989. Movimento di uomini tra l'Egitto e la Sicilia (III-I sec. a.C.). In: Criscuolo, L., and G. Geraci, eds., Egitto e storia antica dall'Ellenismo all'età araba. atti del colloquio internazionale (Bologna, 31 agosto - 2 settembre 1987) : bilancio di un confronto. Bologna, CLUEB: 513-553. 
Mayerson, P., 2006. The Modius as a Grain Measure in Papyri from Egypt. BASP 42: 107-111.

Nantet, E., 2012. Les muriophoroi : état historiographique. In: Chankowski, V., Karvonis, P., eds., Tout vendre, tout acheter. Structures et équipements des marchés antiques. Actes du colloque international d'Athènes (17-19 juin 2009). Bordeaux, Ausonius: 341-344.

Nantet, E., 2016. Phortia. Le tonnage des navires de commerce en Méditerranée du VIIIe siècle avant l'ère chrétienne au VIIe siècle de l'ère chrétienne. Rennes, Presses Universitaires.

Pomey, P., and Tchernia, A., 1978. Le tonnage maximum des navires de commerce romains. Archaeonautica 2: 233-251.

Pomey, P., and Tchernia, A., 2006. Les inventions entre l'anonymat et l'exploit: le pressoir à vis et la Syracusia. In: Lo Cascio, E., ed., Atti convegno Innovazione tecnica e progresso economico nel mondo romano, Atti Incontri capresi, Capri 2003, Baris, Edipuglia: 81-99.

Rougé, J., 1984. Le confort des passagers à bord des navires antiques. Archaeonautica 4: 223-242.

Salviat, F., 1987. Le Navire géant de Hiéro de Syracuse. Tropis 2: 299-303.

Santagati Ruggeri, E., 1996. Osservazioni sui rapporti tra Egitto e Sicilia in età ellenistica. Kokalos 42: 275281.

Torr, C., 1895. Ancient Ships. Cambridge, University Press (reed. 1964).

Turfa, J.M., and A.G. Steinmayer, 1999. The Syracusia as a Giant Vessel. IJNA 28: 105-125.

Walthall, A., 2011. Magistrate Stamps on Grain Measures in Early Hellenistic Sicily. ZPE 179: 159-169.

Zevi, F., 2001. Le Invenzioni di Archimede et le grandi navi. In: Giacobelli, M., ed., Lezioni Fabio Faccenna. Conferenze di archeologia subacquea (I-II ciclio). Bari, Edipuglia: 95-114. 